\title{
Hubungan Antara Status Gizi dan Malaria Falciparum Berat di Ruang Rawat Inap Anak RS. St.Elisabeth Lela, Kabupaten Sikka, Flores, NTT
}

\author{
Theresa Laura Limanto \\ RSK Vincentius s Paulo, Surabaya
}

Latar belakang. Diseluruh dunia ditemukan 15 juta kasus malaria dengan 38.000 kematian tiap tahun. Di wilayah Indonesia bagian Timur, hanya $10 \%$ kasus malaria mendapat perawatan di fasilitas kesehatan yang memadai. Dilain pihak, malnutrisi bertanggung jawab pada lebih dari $50 \%$ angka kematian balita tiap tahun di negara berkembang. ${ }^{2}$ Malnutrisi juga meningkatkan risiko terhadap penyakit infeksi dan peningkatan angka kematian akibat penyakit infeksi tersebut.

Tujuan. Menilai hubungan an tara status gizi dengan timbulnya penyulit pada malaria falciparum pada pasien usia 0-12 tahun yang dirawat di ruang rawat inap RS.St.Elisabeth Lela, kabupaten. Sikka, Flores, NTT.

Metode. Dilakukan studi potong lintang dengan jumlah subjek 66 pasien malaria falciparum berusia 0-12 tahun di ruang rawat inap anak. Data didapat dari anamnesis, pemeriksaan fisik, dan laboratorium. Hasil. Didapatkan 32 subjek dengan status gizi baik dan 3 subjek gizi buruk. Sembilanbelas subjek malaria falciparum menunjukkan satu atau lebih penyulit. Distres pernapasan adalah penyulit terbanyak yang ditemukan, pada 17 subjek. Uji chi square, ditemukan $\mathrm{X}^{2}$ hitung sebesar 11,419 dan koefisien kontingensi 0,384 .

Kesimpulan. Timbulnya penyulit pada malaria falciparum memiliki korelasi terhadap status gizi pasien, dengan kuat hubungan sebesar 0,384 kali. (Sari Pediatri 2010;11(5):363-6).

Kata Kunci. Status gizi, penyulit pada malaria falciparum.

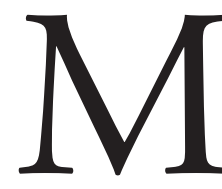
alaria adalah penyakit tropik infeksi yang masih menjadi permasalahan kesehatan masyarakat di Indonesia. Selain mempengaruhi angka kematian

\footnotetext{
Alamat korespondensi:

Dr. Theresa Laura Limanto. Dokter umum post PTT kabupaten Sikka, Flores, NTT. Alamat pengarang: Kendangsari V/31 Surabaya. Telepon: 081332737157. Email: itstheresahere@yahoo.com
}

dan kesakitan bayi, balita, dan ibu melahirkan, malaria juga menurunkan produktifitas penduduk. ${ }^{3}$ Daerah endemis malaria di Indonesia dengan jumlah kasus yang tinggi dilaporkan berasal dari provinsi Papua, Nusa Tenggara Timur, Maluku, Maluku Utara dan Sulawesi Tenggara. ${ }^{1}$ Di dunia, ditemukan 15 juta kasus malaria dengan 38.000 kematian tiap tahunnya. Di wilayah Indonesia bagian Timur, hanya 10\% kasus malaria yang tertangani oleh fasilitas kesehatan yang memadai. ${ }^{2,3}$ Malnutrisi bertanggung jawab pada 
lebih dari $50 \%$ angka kematian balita tiap tahun di negara berkembang. Dalam berbagai derajat, malnutrisi meningkatkan risiko terhadap penyakit infeksi dan angka kematian akibat penyakit infeksi tersebut. ${ }^{2,4}$ Tujuan penelitian untuk mengetahui apakah terdapat hubungan antara timbulnya penyulit malaria falciparum dengan status gizi.

\section{Metode}

Studi potong lintang dilakukan pada pasien usia 0-12 tahun di ruang rawat inap RS.St.Elisabeth Lela, Flores, NTT dalam rentang waktu 1 Juli 2008 sampai dengan 31 Januari 2009. Sumber data adalah data primer yang berasal dari anamnesis, pemeriksaan fisik dan laboratorium. Sampel diambil berdasarkan kriteria inklusi semua pasien malaria falciparum di ruang rawat inap anak yang berusia 0-12 tahun pada rentang waktu penelitian dan bersedia dilibatkan dalam penelitian. Diagnosis malaria falciparum dibuat berdasarkan kriteria (1) demam paroksismal, yakni beberapa serangan demam diselingi interval tertentu, dan pada pengukuran suhu aksilar $\geq 37,5^{\circ} \mathrm{C}$, (2) ditemukan parasit Plasmodium falciparum pada pemeriksaan sediaan darah tetes tebal dan tipis. ${ }^{1,4,5}$ Kriteria eksklusi jika tidak didapatkan Plasmodium atau didapatkan selain Plasmodium falciparum dan jika ditemukan lebih dari satu jenis Plasmodium pada pemeriksaan laboratorium sediaan tetes tebal dan tipis.

Variabel status gizi ditentukan berdasarkan berat badan pasien dalam kilogram dibagi berat badan menurut median WHO-NCHS yang sesuai dengan umur pasien. Status gizi digolongkan baik, jika berat badan $80 \%-120 \%$, gizi kurang 60\%-79\%, dan gizi buruk kurang dari $60 \%$ SD. ${ }^{6}$

Variabel penyulit pada malaria falciparum ditentukan berdasarkan kriteria pemeriksaan fisik dan laboratorium, (1) hiperpireksia, suhu rektal $\geq 41^{\circ} \mathrm{C}$, (2) penurunan kesadaran atau koma berdasarkan APVU (alert, vioce, pain, conciousness), (3) terdapat kejang umum, (4) asidosis, ditandai pernapasan dalam dan cepat (Kusmaull), (5) distres pernapasan ditandai tarikan dinding dada bagian bawah ke dalam dan peningkatan frekuensi pernapasan $\geq 60 \mathrm{kali} /$ menit pada usia $<2$ bulan, frekuensi pernapasan $\geq 50 \mathrm{kali} / \mathrm{menit}$ pada usia $2-11$ bulan atau frekuensi pernapasan $\geq 40 \mathrm{kali} /$ menit pada usia $>1$ tahun, (6) perdarahan spontan, (7) syok ditandai nadi cepat dan lemah sampai tidak teraba, akral dingin, capillary refill time (CRT) >3 detik, (8) ikterik, (9) anemia berat kadar hemoglobin $<5 \mathrm{~g} / \mathrm{dl}$ dan hematokrit (Hct) $<15 \%$, (10) hipoglikemia, kadar gula darah sewaktu $<45 \mathrm{mg} / \mathrm{dl}$. ${ }^{1,4,5}$ Jika ditemukan satu atau lebih penyulit dari pemeriksaan fisik dan laboratorium, maka digolongkan malaria falciparum berat. Jika tidak ditemukan satupun tanda dan gejala dari kriteria tersebut, maka digolongkan menjadi malaria falciparum tanpa penyulit. ${ }^{1,45}$ Data disajikan dalam bentuk tabel distribusi frekuensi. Uji statistik yang digunakan adalah chisquare menggunakan program SPSS versi 12.0 dengan tingkat kemaknaan $\alpha=0,05$.

\section{Hasil}

Jumlah sampel yang memenuhi kriteria inklusi 66 pasien, karakteristik subjek tertera pada Tabel 1. Distribusi status gizi tertera pada Tabel 1. Berdasarkan kriteria pemeriksaan fisik dan laboratorium malaria falciparum, 19 subjek mempunyai satu atau lebih tanda dan gejala penyulit, 7 subjek di antaranya berusia kurang dari satu tahun (Tabel 3).

Penyulit terbanyak pada malaria falciparum adalah distres pernafasan, hiperpireksia, dan anemia berat (Tabel 4).

Tabel 1. Distribusi karakteristik subjek penelitian $(\mathrm{n}=66)$

\begin{tabular}{ll}
\hline Karakteristik & $\mathrm{n}$ \\
\hline Jenis kelamin & \\
Laki-laki & 30 \\
Perempuan & 36 \\
Usia (tahun) & \\
$0-<1$ & 18 \\
$1-12$ & 48 \\
\hline
\end{tabular}

Tabel 2. Distribusi status gizi $(\mathrm{n}=66)$

\begin{tabular}{lcc}
\hline Status gizi & $\mathrm{n}$ & $\%$ \\
\hline Baik & 32 & 48,5 \\
Kurang & 31 & 47,0 \\
Buruk & 3 & 4,5 \\
\hline
\end{tabular}

Tabel 3. Distribusi malaria falciparum berat terhadap umur

\begin{tabular}{lcc}
\hline Malaria falciparum & \multicolumn{2}{c}{ Rentang umur (tahun) } \\
\cline { 2 - 3 } & $<1$ & $1-12$ \\
\hline Berat & 7 & 12 \\
Tanpa penyulit & 11 & 36 \\
\hline Jumlah & 18 & 48 \\
\hline
\end{tabular}


Tabel 4. Distribusi penyulit pada malaria falciparum $(\mathrm{n}=66)$

\begin{tabular}{lc}
\hline Karakteristik penyulit & $\mathrm{n}$ \\
\hline - Hiperpireksia, suhu rektal $\geq 41{ }^{\circ} \mathrm{C}$ & 8 \\
- Distres napas, peningkatan frekuensi napas & 17 \\
$\quad$ dan tarikan dinding dada & 3 \\
- Anemia berat & \\
\hline
\end{tabular}

Dari tabulasi silang antara variabel status gizi dan penyulit pada malaria falciparum, ditemukan bahwa dari 19 pasien malaria falciparum berat, 3 pasien memiliki status gizi baik. Enam belas pasien sisanya terdiri dari 13 pasien dengan status gizi kurang, dan 3 pasien dengan status gizi buruk (Tabel 5).

Dari uji korelasi chi square, didapatkan $\mathrm{X}^{2}$ hitung 11,419 dengan angka signifikansi 0,001, maka disimpulkan ada hubungan antara status gizi dan timbulnya penyulit pada malaria falciparum. penyebab malaria, faktor pejamu turut berperan dalam menentukan kondisi klinis. Di daerah endemis, usia pasien yang terinfeksi parasit turut menjadi penentu derajat keparahan penyakit. Penyulit terbanyak yang ditemukan adalah distres pernafasan, hiperpireksia, dan anemia berat. Gangguan sistem respirasi adalah penyulit yang tidak asing dijumpai terutama pada malaria falciparum akut. ${ }^{7}$ Fujioka dan Aikawa dikutip dari Daily $\mathrm{J}^{7}$ menemukan bahwa late-stage thropozoites dan schizonts dari P.falciparum memiliki kemampuan sitoaderensi pada mikrovaskular dan menyebabkan sekuesterisasi sistim sirkulasi yang kemudian mengambil peranan penting pada manifestasi klinis yang berat. ${ }^{7}$ Hal serupa disampaikan Corbett dkk dikutip dari Daily J7 bahwa sekuesterisasi pada mikrovaskular sistim respirasi akan tampak secara klinis sebagai gangguan sistim pernafasan. Pasien malaria anak yang mengalami distres nafas sering menunjukkan gangguan

Tabel 5. Tabulasi silang variabel status gizi dan penyulit pada malaria falciparum

\begin{tabular}{lcccc}
\hline & & \multicolumn{2}{c}{ Penyulit } & Total \\
\cline { 2 - 4 } & Malaria berat & Malaria tanpa penyulit & \\
\hline Status gizi & Gizi baik & 3 & 29 & 32 \\
\cline { 2 - 5 } & $\begin{array}{c}\text { Gizi kurang atau gizi } \\
\text { buruk }\end{array}$ & 16 & 18 & 34 \\
\hline Total & 19 & 47 & 66 \\
\hline
\end{tabular}

\section{Diskusi}

Malaria disebabkan oleh parasit Plasmodium dan ditularkan melalui gigitan nyamuk Anopheles betina. Kelompok risiko tinggi yang rawan terinfeksi adalah bayi, anak dan ibu hamil. ${ }^{1}$ Diagnostik pasti malaria ditegakkan berdasarkan ditemukannya parasit Plasmodium pada pemeriksaan sediaan darah tetes tebal dan tetes tipis. ${ }^{5}$ Kasus malaria berat disebabkan oleh Plasmodium falciparum, disertai satu atau lebih penyulit hiperpireksia, penurunan kesadaran sampai koma, kejang umum, asidosis, distres nafas, perdarahan spontan, syok, ikterus, anemia berat dan hipoglikemia. ${ }^{1,4,5}$ Dari 66 pasien yang diteliti, 19 pasien diantaranya mengalami malaria berat, dan 7 pasien berusia kurang dari satu tahun. Daily $\mathrm{J} \mathrm{dkk}^{7}$ mengemukakan bahwa malaria berat berkorelasi terhadap usia dan intensitas transmisi Plasmodium, usia $>6$ bulan sampai usia $<3$ tahun lebih rentan mengalami klinis berat dibanding kelompok usia lain. ${ }^{7}$ Tanpa mengesampingkan jenis Plasmodium mikrovaskular sistem respirasi. Diterangkan bahwa schizonts dari P.falciparum yang pecah, mengeluarkan malarial toxin yang merangsang respon sitokin dan memberi kontribusi terhadap fenomena neurologis dan hipertermia. ${ }^{7}$ Anemia berat terutama disebabkan eritrolisis akibat parasitemia, mekanisme lain yang diduga turut berperan adalah hemolisis ekstravaskular, eritofagositosis baik pada eritrosit yang terinfeksi parasit maupun yang tidak terifeksi dan supresi pada sumsum tulang yang menyebabkan diseritropoesis. ${ }^{7}$ Pada tabulasi silang ditemukan dari 19 pasien mengalami malaria falciparum berat, 3 pasien diantaranya memiliki status gizi baik. Uji korelasi chi square, didapatkan koefisien kotingensi 0,384 , berarti timbulnya penyulit pada malaria falciparum memiliki hubungan terhadap status gizi. Grigsby dkk dikutip dari Harohalli RS $^{8}$ menemukan bahwa meneliti bahwa malnutrisi dapat mengubah respon imun. Jumlah limfosit $T$ akan berkurang, respon limfosit tidak memadai (impaired lymphocyte response), beberapa jenis sitokin dan komplemen akan menurun jumlahnya mengakibatkan 
respon fagositosis menurun. Sekresi IgA dilaporkan juga mengalami penurunan. Perubahan sistim imun ini pada akhirnya meningkatkan predisposisi anak untuk mengalami infeksi atau jatuh ke dalam keadaan infeksi yang berat atau kronis. ${ }^{8}$

\section{Kesimpulan}

Ditemukan 32 pasien berstatus gizi baik, 31 gizi kurang, dan 3 mempunyai gizi buruk. Sembilan belas pasien mengalami malaria falciparum berat, 13 diantaranya memiliki status gizi kurang dan 3 berstatus gizi buruk. Penyulit terbanyak yang ditemukan adalah distres pernapasan. Timbulnya penyulit pada malaria falciparum memiliki hubungan dengan status gizi.

\section{Daftar P ustaka}

1. Direktorat Jendral PPM \& PLP, Departemen Kesehatan Republik Indonesia. Pedoman penatalaksanaan kasus malaria di Indonesia. Jakarta 2006.h.1-30.

2. Estey J. Kesehatan dan gizi. 2006. Diunduh dari URL:http://www.unicef.org/indonesialid/health nutrition 3130. html. Diakses tanggal 23 Desember 2008.

3. Badan Litbang Kesehatan, Departemen Kesehatan Republik Indonesia. Studi kejadian malaria pada anak di suku anak dalam kabupaten Musi Banyuasin tahun 2006. Diunduh dari URL:http://www.litbang.depkes. go.id/risbinkes/Buku\%20Laporan\%20Penelitian\%202006/ malaria\%20suku\%20anak\%20dalam.html. Diakses tanggal 23 Desember 2008.

4. Pusponegoro HD, Hadinegoro SRS, Firmanda D, penyunting. Standar pelayanan medis kesehatan anak. Edisi ke-1. Jakarta: Badan penerbit IDAI; 2004.h.119220.

5. Direktorat Jendral Bina Pelayanan Medik, Departemen Kesehatan Republik Indonesia. Pelayanan kesehatan anak di rumah sakit: pedoman bagi rumah sakit rujukan tingkat pertama di kabupaten. Jakarta 2008.h.84-175.

6. Supariasa IDN, Bakri B, Fajar I. Penilaian status gizi. Jakarta: Penerbit buku kedokteran EGC; 2001.h.56260.

7. Daily J. Malaria. Dalam: Gershon A, Hotez P, Katz S, penyunting. Krugman's Infectious Diseases of Children. Edisi kesebelas. Philadelphia: Mosby; 2004.h.337-48.

8. Harohalli RS, Donna GG. Malnutrition, 2006. Diuduh dari URL:http://www.emedicine.medscape.com/article/985140overview. Diakses pada 9 Januari 2009. 